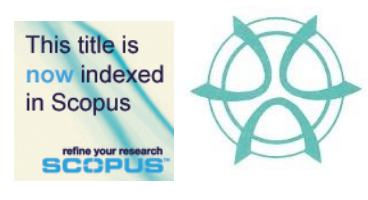

PLANNING MALAYSIA:

Journal of the Malaysian Institute of Planners

VOLUME 16 ISSUE 4 (2018), Page 15 - 33

\title{
SPATIAL REGENERATION OF MUSLIM BURIAL PRACTICES IN THE METROPOLITAN AREAS OF KUALA LUMPUR AND JAKARTA
}

\author{
Mohamad Reza Mohamed Afla ${ }^{1}$ \\ ${ }^{1}$ School of Housing, Building and Planning \\ UNIVERSITI SAINS MALAYSIA
}

\begin{abstract}
This article focuses on the subject of burial practices which are performed by the Muslim population and the management at public cemeteries within the metropolitan areas of Kuala Lumpur and Jakarta. This research examines specifically, the conventional way of burial practice by the majority of the Muslim population. Unlike other major religions in Southeast Asia which are more open and flexible in the disposal of corpses, full body burial is mandatory in Islam. In response to the escalating issue of lack of space and land shortage for Muslim cemetery, local authorities of the two metropolitan areas have identified alternatives and solutions in handling these alarming situations. This research has recognised factors that lead to these problems, as well as discussing available methods to overcome these issues. The finding exhibits Muslim cemetery's layout to be problematic due to abundance of burial practices accumulated by patrons which led to disorganisation of space and claustrophobia. This article concludes by providing proposals and design guidelines at the terrain level, together with recommendations that emphasise the long-term usage of the grave plots.
\end{abstract}

Keywords: burial practices, spatial, cemeteries, metropolitan 
Mohamad Reza Mohamed Afla

Spatial Regeneration of Muslim Burial Practices in the Metropolitan Areas of Kuala Lumpur and Jakarta

\section{INTRODUCTION}

This article explores alternative methods and strategies for burial practices within the context of rapid development of urban cemeteries. The main question of this research is how the metropolitan cities of Kuala Lumpur (KL) and Jakarta deal with the issue of burial. The intention of this research is to offer alternative solutions to the critical situation of overcrowding and land shortage in Muslim cemeteries (Rahim, 2011; "No more space", 2011). This study argues that some aspects of Muslim funerary practices should be altered and indeed transformed, especially given the increasing pressure of urbanisation in Kuala Lumpur, Singapore and Jakarta (Hamnett \& Forbes, 2011, Rimmer, \& Dick, 2009; Forbes, 1996). In addressing the issue regarding the lack of space for Muslim burials in the cities, there are some modifications that could be employed in order to attain a higher level of efficiency in utilising the space inside cemeteries (Ely \& Howe, 2002).

The objectives of this research are to analyse alternatives for graves arrangement by considering the burial practices of local Muslims and to explore adaptability of graves layout by examining the requirements of Islamic burials.

\section{METHODOLOGY}

The case studies presented in this article will provide an insight into the current state of urban cemeteries and practices employed for Muslim burials within Kuala Lumpur and Jakarta. Site observation has been conducted at selective sites in each city in order to examine closely the current trends associated with Muslim burial practices and to provide a basis for potential improvements. These are identified as catalysts in changing the burial practices of Muslim communities in Kuala Lumpur and Jakarta. There are five case studies involved in this research as shown in Table 1. In Kuala Lumpur metropolitan area, KL-Karak Muslim Cemetery (KLKMC) and Taman Selatan Muslim Cemetery (TSMC) are among the sites that have been chosen. Meanwhile, Karet Bivak General Cemetery (KBGC), Pondok Kelapa General Cemetery (PKGC) and San Diego Hills Memorial Park (SDHMP) are the sites that have been chosen for the Jakarta metropolitan area. These sites have been selected as the case studies as they have each employed a spatial solution as a new approach in managing the grave plots for Islamic burial.

The case studies in this research are used in five ways. Firstly, the case studies are consistently addressed in discussing the problems that relate to the urban cemeteries in the metropolitan areas of KL and Jakarta. They are drawn upon as examples to discuss the gravity of the situation within the sites. Secondly, examples of case studies are used in searching for reliable approaches that are consistent with Muslim burial practices. Thirdly, they are used to indicate similar and shared characteristics and to highlight certain contradictory features. Fourthly, the case studies are used to provide information which may lead to 
PLANNING MALAYSIA

Journal of the Malaysia Institute of Planners (2018)

better utilisation of Muslim cemeteries. Lastly, the case studies are used to support ideas or arguments in this article.

Table 1: Table of spatial solution at the terrain level employed at selected case studies

\begin{tabular}{|c|c|c|c|}
\hline Case Studies & $\begin{array}{c}\text { Area } \\
\text { (Acre) }\end{array}$ & Remarks & $\begin{array}{l}\text { Spatial Solution Employed } \\
\text { for Islamic Burial } \\
\end{array}$ \\
\hline $\begin{array}{l}\text { 1. KL-Karak Muslim } \\
\text { Cemetery } \\
\text { (KLKMC), Kuala } \\
\text { Lumpur, Malaysia }\end{array}$ & 92 & $\begin{array}{l}\text { The largest burial ground for } \\
\text { Muslims that serves Kuala } \\
\text { Lumpur metropolitan area. }\end{array}$ & $\begin{array}{l}\text { - Minimising the amount of } \\
\text { permanent structures } \\
\text { within cemetery area. }\end{array}$ \\
\hline $\begin{array}{l}\text { 2. Taman Selatan } \\
\text { Muslim Cemetery } \\
\text { (TSMC), } \\
\text { Putrajaya, } \\
\text { Malaysia }\end{array}$ & 23 & $\begin{array}{l}\text { The latest model for urban } \\
\text { cemeteries in Kuala Lumpur } \\
\text { metropolitan area. }\end{array}$ & 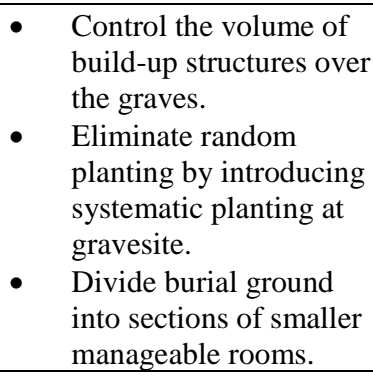 \\
\hline $\begin{array}{l}\text { 3. Karet Bivak } \\
\text { General Cemetery } \\
\text { (KBGC), Central } \\
\text { Jakarta, Indonesia }\end{array}$ & 40 & $\begin{array}{l}\text { One of the largest general } \\
\text { cemeteries in the city where } \\
\text { removal of tombstones and } \\
\text { greening the field are being } \\
\text { practiced. }\end{array}$ & 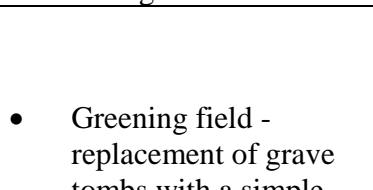 \\
\hline $\begin{array}{l}\text { 4. Pondok Kelapa } \\
\text { General Cemetery } \\
\text { (PKGC), East } \\
\text { Jakarta, Indonesia }\end{array}$ & 41 & $\begin{array}{l}\text { Another public cemetery in } \\
\text { Jakarta that also practices } \\
\text { the removal of tombstones } \\
\text { and greening the field. }\end{array}$ & $\begin{array}{l}\text { tombs with a simple } \\
\text { plaque. }\end{array}$ \\
\hline $\begin{array}{l}\text { 5. San Diego Hills } \\
\text { Memorial Park } \\
\text { (SDHMP), } \\
\text { Karawang Barat, } \\
\text { Indonesia }\end{array}$ & 575 & $\begin{array}{l}\text { A regional scale urban } \\
\text { cemetery that serves } \\
\text { Jabodetabek city region. }\end{array}$ & $\begin{array}{ll}\text { - } & \text { Eliminate random } \\
\text { planting by introducing } \\
\text { systematic planting at } \\
\text { gravesite. } \\
\text { Divide burial ground } \\
\text { into sections of smaller } \\
\text { manageable rooms. }\end{array}$ \\
\hline
\end{tabular}

Source: Author (2012)

\section{STAGES IN MUSLIM BURIAL PRACTICE}

Muslim burial practices at the terrain level involve two stages which take place before and after the burial (Figure 1). Initially preparation of the site is usually undertaken by the management of the cemeteries as part of the process of full body burial. In most cases the grave plots have been prepared in accordance with the authorities' guidelines and the Islamic precept. For example, the orientation of the graves must be aligned with qiblah, as Islam requires the corpse to face in that direction (Hashim, 2007). The grave arrangements in Muslim cemeteries are commonly based on a grid system (Iqba, 2011) and each grave plot has a marking 
Mohamad Reza Mohamed Afla

Spatial Regeneration of Muslim Burial Practices in the Metropolitan Areas of Kuala Lumpur and Jakarta

stone or its own special number for the purpose of identification in the future (Figure 2).

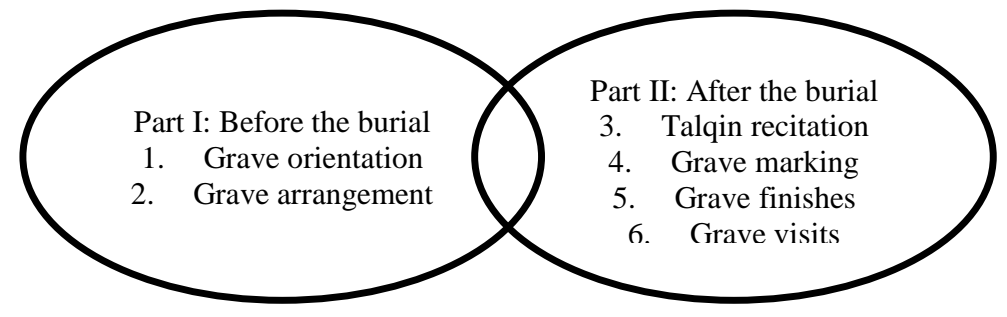

Figure 1: Conventional practices in burial rites as performed by Muslims at the terrain level Source: Author (2012)

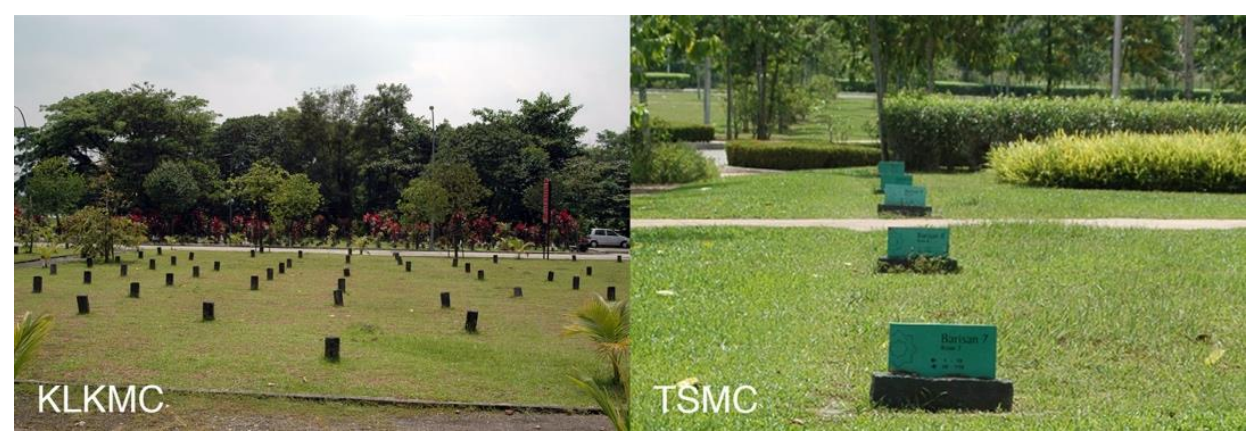

Figure 2: Grave marking stones are used at KLKMC to indicate the exact position of burial plots, whereas, a more systematic approach is practiced at TSMC to assist people to locate their graves during a visit.

Source: Author (2012)

At the latter stage of Muslim burial practice, the closing of the funeral ceremony begins with the Imam reciting talqin to the deceased accompanied by the mourners. When performing this ritual, the Imam will commonly be seated on the ground next to the grave, close to the head of the corpse (Hashim, 2007), while the crowd will generally occupy available spots around the grave. People are allowed to leave after the talqin recitation has finished. The ritual of the talqin recitation happens shortly after the burial, whereas the marking of the grave is an ongoing process as relatives and friends visit on various occasions over many years. During this time, gravestones will be erected as a way to properly mark the resting place of the deceased and in most cases, this activity will be accompanied or followed by a monument and various forms of permanent structures placed over the grave.

There are obviously some contradictions between the burial practice ordained by Islam and those that are performed by the surviving family members; 
PLANNING MALAYSIA

Journal of the Malaysia Institute of Planners (2018)

these require some explanation. It is important to differentiate between the custom of decorating the graves and the grave marking. The grave finish should not look the same as the grave marking, even though they share similar functions. This is because Islam has explicitly determined the way graves should be built. In terms of the grave's physical appearance, there are three things prescribed by Islam that should be followed by Muslims. Firstly is the erection of the headstone with an inscription of the deceased's details (Hashim, 2007; Omer, 2008); secondly is the planting of a smaller tree or shrub near the grave (Dafni, Lev, Beckmann, \& Eichberger, 2006, Hashim, 2007); and finally, the grave's surface is raised above the ground level to form a mound-like shape (Ismail, 2008; Omer, 2008). However, contrary to this religious teaching, intricate grave structures have become common practice and are regarded as part of the custom in Muslim funerary culture. In general, most Muslims today are inclined to have their graves built with extravagant monuments; the extent of detail of the embellishment varies from one grave to another (Figure 3). This can be attributed to personal preference, social status, as well as to the practical purpose of easy recognition of the grave which leads to overcrowding. Thus, there is a need for Muslim graves to be redesigned so as to provide a solution to this problem.

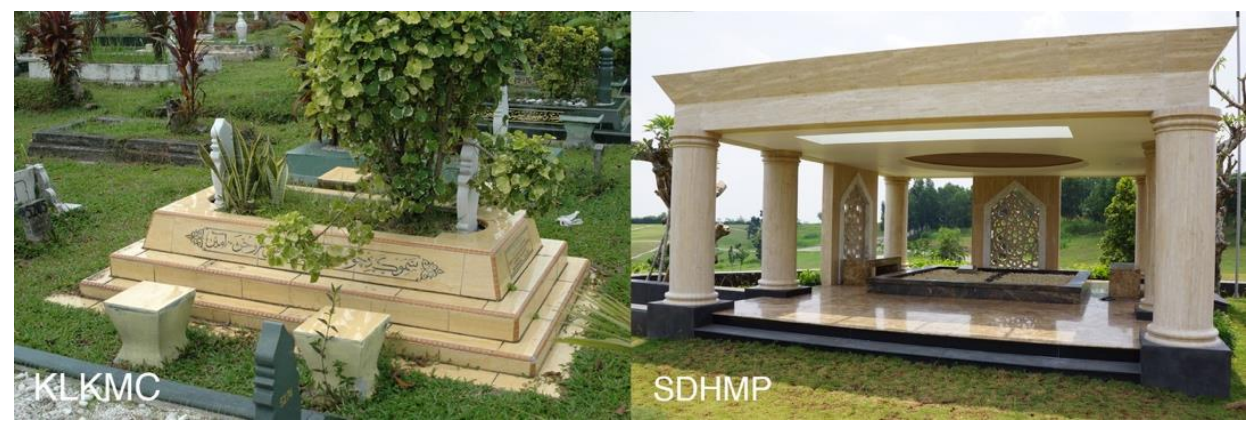

Figure 3: Examples of excessive grave markings and finishes at Muslim cemeteries at KLKMC and SDHMP which do not comply with Islamic burial requirements. Source: Author $(2011,2012)$

The method of grave marking has also progressively evolved with the change of time in order to suit people's tastes. There has been the advent of new materials and techniques in building monuments over Muslim graves. For example, the use of prefabricated graves in TSMC. The case studies show some examples where Muslim graves are becoming more simplified in their physical appearance. The moderation of graves is one possible step to take in managing the lack of space in the cemeteries; TSMC and SDHMP are some of the examples of sites that show this (Figure 4). 
Mohamad Reza Mohamed Afla

Spatial Regeneration of Muslim Burial Practices in the Metropolitan Areas of Kuala Lumpur and Jakarta

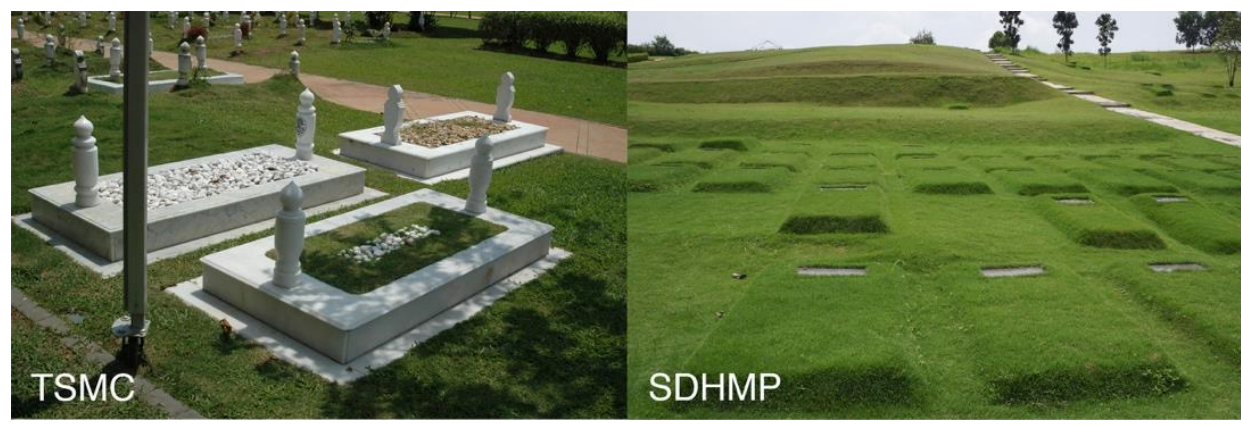

Figure 4: Examples of simplified and moderately designed graves at TSMC and SDHMP, (2011, 2012).

Source: Author $(2011,2012)$

From site observations there is a significant difference between conventional and simplified methods of building graves, in terms of the spatial quality and in improving the environment offering more breathing space for visitors. Apart from being low in cost, simple monuments require less maintenance and it would be sensible for the management of the cemeteries to erect them over Muslim graves. Moreover, the case studies have shown that there will be minimal grave markings by imposing a strict control on the way they are arranged such as is exemplified at TSMC. Therefore, elaborate and extensive grave structures should be re-examined in terms of their function in the cemeteries.

Grave visits are the last ritual in Muslim burial practices. This is a continuing rite for the visitors as a way to commemorate the dead. During this time, visitors will be seated on the ground in order to offer the prayer to the deceased by reciting a chapter of Yasin from the Quran. This practice is usually performed around the grave. The Yasin recitation ends with the spreading of flower petals over the grave with some water. Families may bring a mat or newspaper from home on which they sit temporarily. In some cases, people are inclined to bring seats to place next to the grave in order to be more comfortable during the recitation. However, with the help of grave makers, it is a common thing now for grave structures to be built with seats. The seats vary according to the size and materials from which they are made. Nevertheless, some people are creative in accommodating this ritual by using simple material such as benches. This practice of grave visits sometimes becomes a challenge for the visitors as they have to find available places for seating and this could be difficult with the way graves have been arranged. This situation becomes worse as new graves gradually appear, and because of the abundance of grave structures and the scattered use of trees and shrubs planted close to the graves. Muslims visit the graves at certain times of the year and the claustrophobic environment that sometimes results can potentially generate unpleasant experiences, which can be 
PLANNING MALAYSIA

Journal of the Malaysia Institute of Planners (2018)

observed in some of the case studies such as KLKMC and KBGC (Figure 5).

Apart from this, a common factor that has been observed on these sites is that there are gaps between the graves. These could be eliminated to maximise the use of land (see Figure 6). This raises the question, whether it is possible to arrange graves next to each other without decreasing people's need to perform their rituals. A suggestion to remove the interval space between graves would probably create more room for burial plots. As mentioned before, these interval spaces are normally occupied. For instance, there have been many structures both permanent and temporary that have been found by the grave-sites in every visited site. Nevertheless, the issue of visibility and accessibility during the grave visits cannot simply be disregarded. There is a need to consider greater accessibility, as well as visibility, for the visitors. Visitors find it hard to search for their family graves due to the layout of burial plots. Therefore, a new approach has to be initiated in order to facilitate spatial efficiency and grave visit rituals.

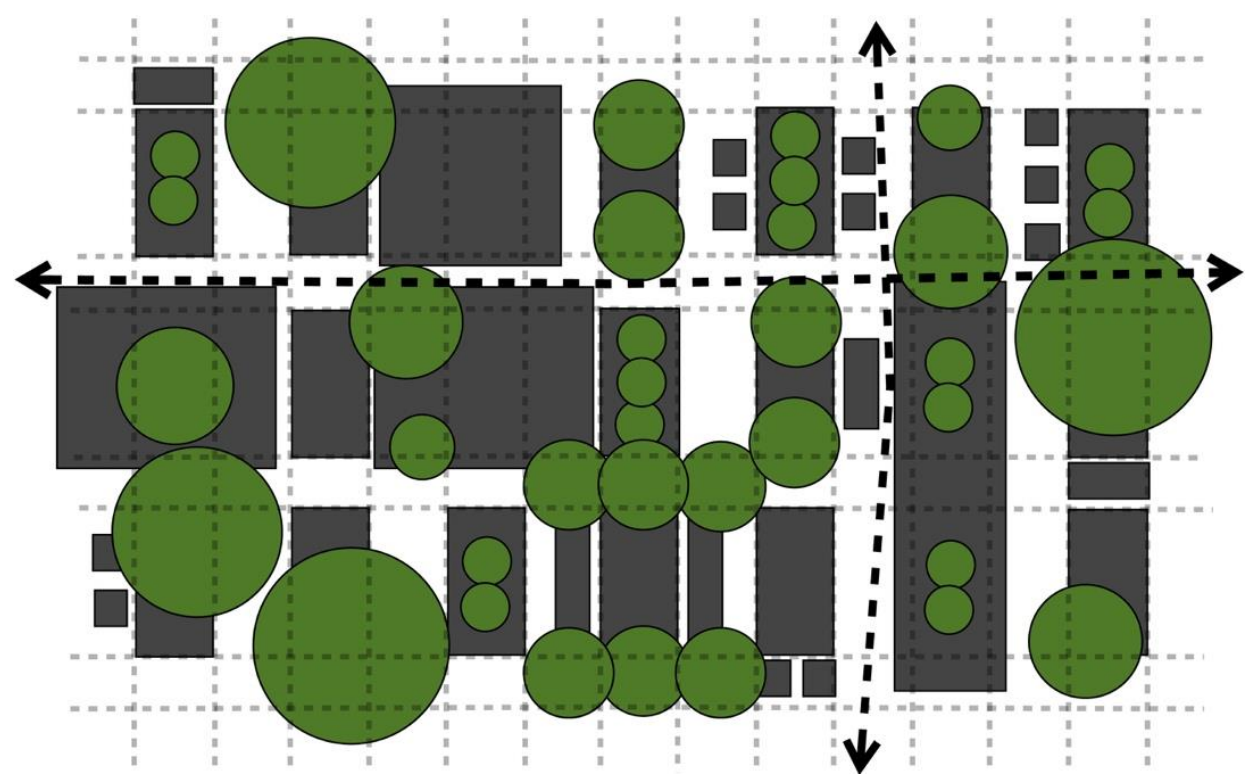

Figure 5: A schematic plan shows typical chaotic landscape environment in public cemeteries, which results from Muslim burial practices.

Source: Author (2012) 
Mohamad Reza Mohamed Afla

Spatial Regeneration of Muslim Burial Practices in the Metropolitan Areas of Kuala Lumpur and Jakarta

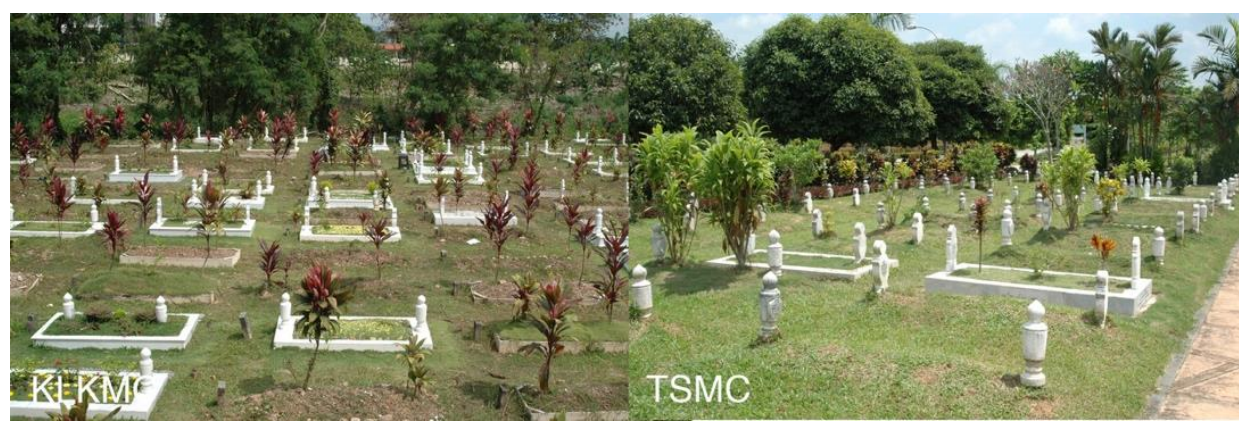

Figure 6: Often there are gaps between the graves that could be eliminated to maximise the use of land in the cemeteries Source: Author (2011)

\section{THREE CATEGORIES OF MUSLIM BURIAL PRACTICE}

The case studies show that Muslim cemeteries in KL and Jakarta share some definite similarities in terms of their funeral practices. Three categories of burial practices have been identified from each case study of Muslim cemeteries in each city. This burial practice is, firstly, made up of family plots, secondly, erected permanent structures, and lastly, the random planting over the graves. These burial practices are considered common traits of Muslim cemeteries.

\section{Family Plots}

This practice has been mentioned in Bougas' report on Muslim cemeteries in Patani (Bougas, 1988). Family plots have existed in the Islamic funerary tradition since the Prophet's time (Omer, 2008). The logical reasoning behind this practice is to make the grave visiting easier for the deceased's family. Tending activities can be simultaneously done without having to move from one grave to another. This also applies to the practice of offering prayers to the dead during the grave visits. As a matter of fact, sharing a single grave with multiple bodies is permissible in the event where the area for burial is inadequate (Hashim, 2007). The problem in today's public cemeteries is that this practice is hard to follow because most public cemeteries do not accommodate family plots, as people are not allowed to book burial plots in advance. There is also no guarantee that family members will be buried in the same spot nor at the same time. The need for burial has always been a priority for the family members of the deceased. However, this practice still exists in Muslim cemeteries such as KLKMC, KBGC, PKGC and SDHMP (Figure 7). The application of family plots is still relevant in Muslim society today, but somehow its significance has not been fully recognised.

Even though Muslims are encouraged to have their family graves within one spot, Islam does not describe how this should be done. Unlike memorial parks, where family plots can be bought in advance, in general, Muslim graves cannot be procured until death has actually occurred. However, this contradicts 
PLANNING MALAYSIA

Journal of the Malaysia Institute of Planners (2018)

the Islamic view which urges Muslims to have family plots in one spot. This religious misinterpretation should be eradicated from the current practice. Although grave reservation has already been made available to Muslims at SDHMP (Kurniawan, 2008), this is not widely practiced in public cemeteries around Jakarta and certainly not in KL.

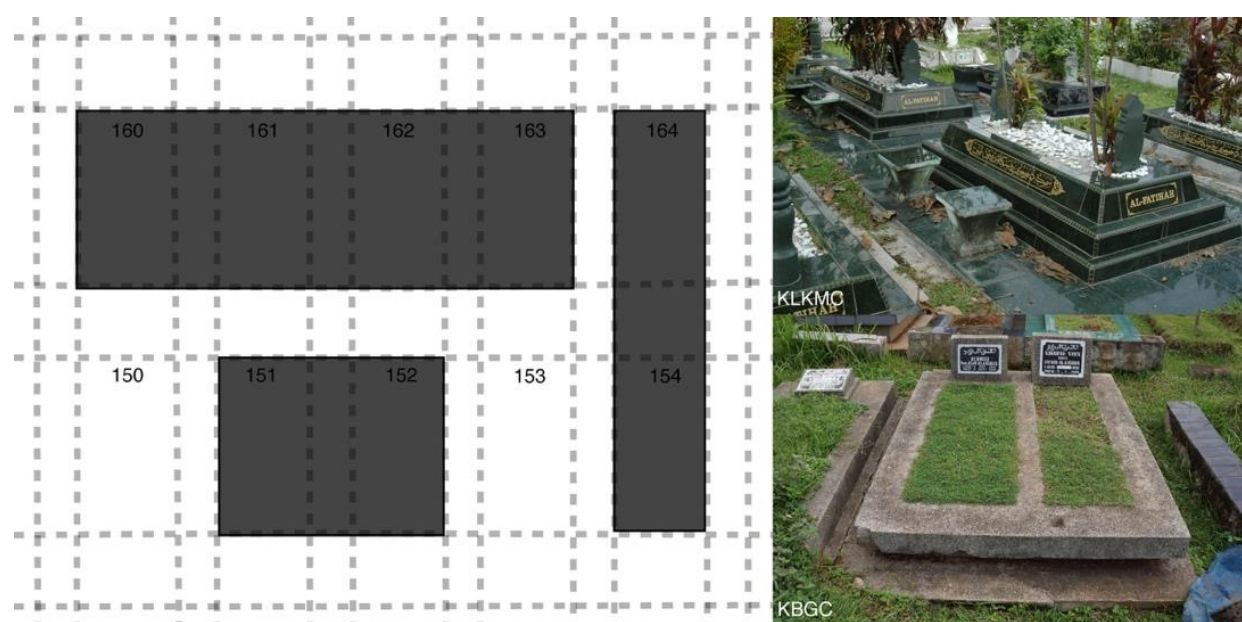

Figure 7: Many forms of family plots have been encountered during the site visits. The diagram on the left depicts some of the arrangements of family plots found in the cemeteries. Pictures on the right show some of the actual family plots found at KLKMC and KBGC.

Source: Author (2011,2012)

\section{Permanent Structures}

Permanent structures at Muslim graves can be divided into three groups: seating, monuments and built up personal demarcation. These structures contribute to the problem of overcrowding in cemeteries because of the nature of a regimented grid layout in Muslim cemeteries.

\section{Seating}

Some seating is built as an extension of the grave, whereas, some is built as a row of stand-alone seats or benches. As previously explained, it has been part of the Muslim custom for the deceased's family or relatives to gather around the grave during the visit. The main focus of this research will be on the permanent seating as it possesses the potential to interfere with neighbouring graves (Figure 8). In order to avoid permanent seating from dominating space between graves, the layout of cemeteries has to be redesigned so that a new arrangement that consumes less space can be introduced. For visitors a convenient seat during the visit is desirable; however it should not be part of the grave itself. This is because the seating structures sometimes limit future grave plots. Removable chairs could 
Mohamad Reza Mohamed Afla

Spatial Regeneration of Muslim Burial Practices in the Metropolitan Areas of Kuala Lumpur and Jakarta

be used to solve this matter and there have been some cases where the management of the cemetery provides this kind of service to visitors, for example in KLKMC and TSMC.

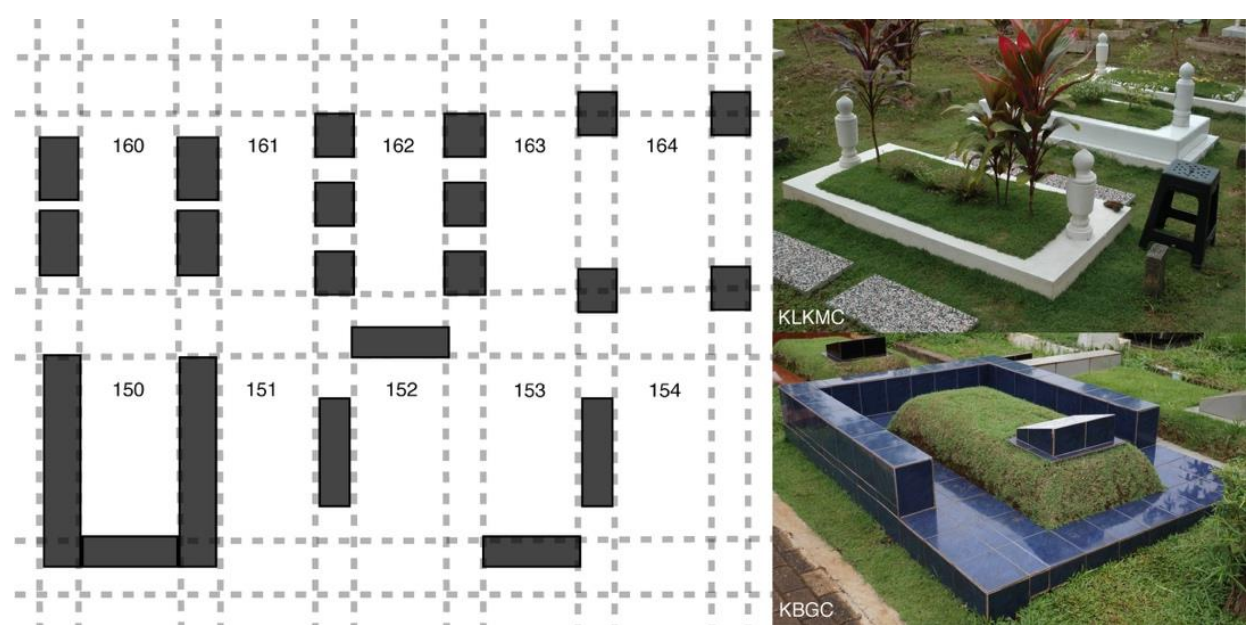

Figure 8: There are many forms of permanent structures that have been encountered during the site visits, including monumental structures and seating structures. The diagram on the left depicts some of the variations of seating structures found in the cemeteries. Pictures on the right show some of the actual seating structures found at KLKMC and KBGC. The top right picture shows the slab-like pieces that were used by the grave's owners to sit on the ground during the visit.

Source: Author (2011, 2012)

\section{Monuments}

Muslims are not encouraged to spend money lavishly on memorial monuments and they should restrict themselves from showing off their wealth through the building of graves (Hashim, 2007; Ismail et al., 2017). According to Omer (2008), Muslims are not encouraged to build grand monuments over the graves as this is considered to be a waste of resources. In every general cemetery visited around both metropolitans, local authorities have a great influence in controlling people's practices over the graves. Some burial practices are bound by the regulations set by the local authorities. There are certain limits and specific dimensions that people have to follow when building a grave monument. For example, with the issuance of bylaw No. 2/1999 in Jakarta, grave structures such as tombs and mausoleums can no longer be built within public cemeteries ("Limited cemetery space", 2011). Under this legislation, graves should not exceed 1.5 metres by 2.5 metres in dimension (("Limited cemetery space", 2011). In most case studies, a clear warning has been displayed on the information board to prohibit people from performing certain burial practices. As a consequence, people do not have complete freedom in building monuments over the graves as they previously had. 
However, most people tend to ignore these regulations.

The decision to follow the Islamic precepts of low profile graves depends on individual belief and intention. It is a question of personal choice, which seems to fit more in the memorial park rather than in public cemeteries. The erection of monumental structures over graves is not only found in Muslim cemeteries, but is practiced in other cultures as well (Francis, 2003). However, there is a need to re-examine this as the impact that grand monuments have on available space is a serious problem. Public cemeteries have commonly refused to cater for the installation of large monuments. Local authorities insist on keeping grave monuments to a minimum size. However, some graves belonging to important figures are still allowed to have grand statues; this can be regarded as a privilege. Nevertheless, monumental structures are still considered as the main part of Muslim graves and people should have the right to choose. This has been exclusively granted to higher class people, but all people should be entitled to the same rights by having a memorial park version of Muslim cemeteries as has been demonstrated at SDHMP. Therefore, the initiative for a different kind of Muslim cemetery ownership is present in KL and Jakarta.

It is important for local authorities to enforce rules about this practice by only allowing minimal construction of monumental structures over graves for two reasons. Firstly, because of the Islamic precept that forbids the glorification of graves and secondly, to minimize the impact of overcrowding within cemeteries (Omer, 2008). Certainly, this will help justify why Muslim graves should no longer possess monumental structures, but rather a simple plaque to record the details of the dead persons. As a matter of fact, the adoption of this simple plaque has been used in KBGC and SDHMP (Figure 9). Out of preference for a green field rather than a concrete landscape, the local authorities have redeveloped general cemeteries in Jakarta, by replacing the existing grave structures including gravestones with a simple plaque. The greening of general cemeteries is a step to counter the immediate urban flooding in Jakarta city (Salim \& Firman, 2011). This step was also introduced to provide the public with alternatives to insufficient green space in the city (Nirmala \& Primanita, 2011, Uslu, Baris, \& Erdogan, 2009). The example of the green field in KBGC and SDHMP provides the possibility of Muslim graves no longer having a solid and permanent epitaph.

No doubt that there have been some changes in the method of constructing the grave monuments where prefabricated graves are in greater evidence within Muslim cemeteries such as in TSMP. The expensive cost of building grave monuments explains this trend. However, some people still prefer to do their own rendition of grave monuments. This is motivated by the strong relationship between people and death, especially in the event of a recent bereavement (Hallam \& Hockey, 2001). There are strong tendencies by some people to personify the graves in their own way rather than leave it to the grave makers. This phenomenon was highlighted by both Gibson (2004) and Doss 
Mohamad Reza Mohamed Afla

Spatial Regeneration of Muslim Burial Practices in the Metropolitan Areas of Kuala Lumpur and Jakarta

(2002), as an ongoing connection that continues to be performed by the bereaved. This serves as a medium to convey multiple meanings and purposes that usually are driven by personal motivations or historical events. A separation of burial sections between grave builders and self-made monuments will probably help to address the differences and needs of every individual.

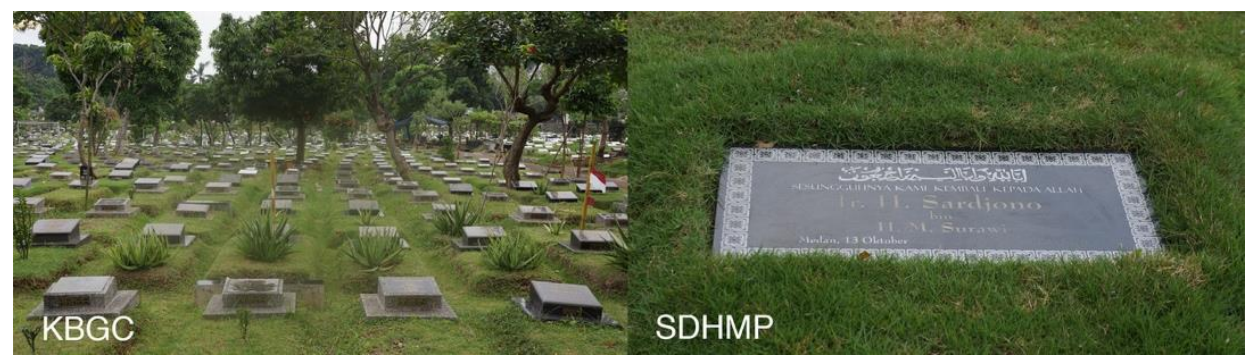

Figure 9: Examples of simple plaques used at KBGC and SDHMP Source: Author (2012)

\section{Built-Up Personal Demarcation}

Extensive grave structures are used to indicate personal demarcation in Muslim cemeteries. In some cases, the personal demarcation can be seen as the extension of monumental structures where the materials are used along the perimeter (Figure 10). Muslims perform this practice for certain reasons - to protect the graves or simply for aesthetic reasons. This practice suggests that people are keen to mark the area of the deceased's grave even though there seems to be a shortage of space. This implies that people have their own beliefs in demonstrating how the graves should look, based on individual taste and preference. According to Hashim (2007), this kind of practice is not permitted in the Islamic teaching and the structures should be demolished because they will disturb other people's graves. However, some graves in Muslim cemeteries do not possess any form of demarcation at all. These graves are found to be modest, while others have nothing on top other than a gravestone. This suggests that some people prefer not to have any kind of demarcation over the graves due to the restriction of religious teaching, or because of insufficient funds.

The case studies show that people have marked the grave areas by using either horizontal or vertical structures. The examples of personal demarcation using both structures can be seen extensively in the grave monuments. Horizontal structures for the grave monuments are usually made of marble or concrete, whereas the vertical structures are made of fences and gates. The use of these structures has created some narrow and confined surrounds within the cemetery areas. The logical explanation behind this phenomenon is that there are no clear boundary lines marked by the management of the cemetery. Even though stone markers have been used to mark the number of the grave plots, these are found to be ineffective, because visitors rarely refer to them to locate the graves. This is 
PLANNING MALAYSIA

Journal of the Malaysia Institute of Planners (2018)

because the stone markers are gradually disappearing from sight due to frequent human activity at the graves. As a result, the stone markers become useless after the gravestones have been erected. A clear marking of the grave plots should be imposed to indicate certain space limitations as well as to enhance a sense of ownership.

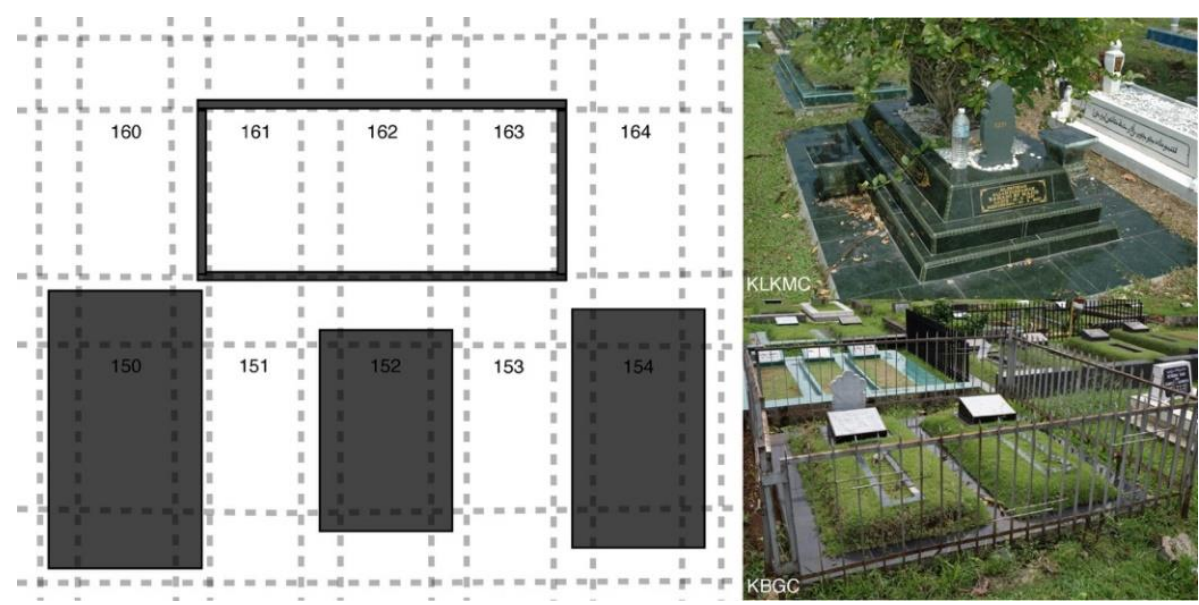

Figure 10: There are many forms of personal demarcation that have been encountered during the site visits. The diagram on the left depicts some of the variations of built-up personal demarcations. Pictures on the right show some of the actual structures found at

KLKMC and KBGC.

Source: Author $(2011,2012)$

\section{Random Planting}

This is the part of the cemetery practice that deals with the softscape elements of the sites. This planting of trees and shrubs is significant in Islamic funeral tradition as a way to ease the suffering of the dead. It is not unusual to find Muslim cemeteries colonised with plants as Muslims believe that the trees and shrubberies are actually praying to the bodies inside the graves (Hashim, 2007). Random plants are considered part of the natural elements. However, as plants and shrubberies are the concern of cemetery patrons rather than the cemetery administration, their proliferation naturally follows a random and haphazard form (Figure 11). Plants have been used at Muslim cemeteries in Patani to serve as temporary grave markers (Bougas, 1988). As explained by Bougas (1988: p. 65), "In Aceh, trees were generally planted as temporary grave markers, and were later replaced when proper tombstones were set. The Malays in Peninsular Malaysia plant trees, side by side, with temporary wooden graves markers". In Muslim cemeteries, this interim role of the trees or shrubberies is still practiced. Shrubberies or trees are added to new graves by the family members. These are normally positioned at both ends of the grave, which is where the head and feet are. 
Mohamad Reza Mohamed Afla

Spatial Regeneration of Muslim Burial Practices in the Metropolitan Areas of Kuala Lumpur and Jakarta

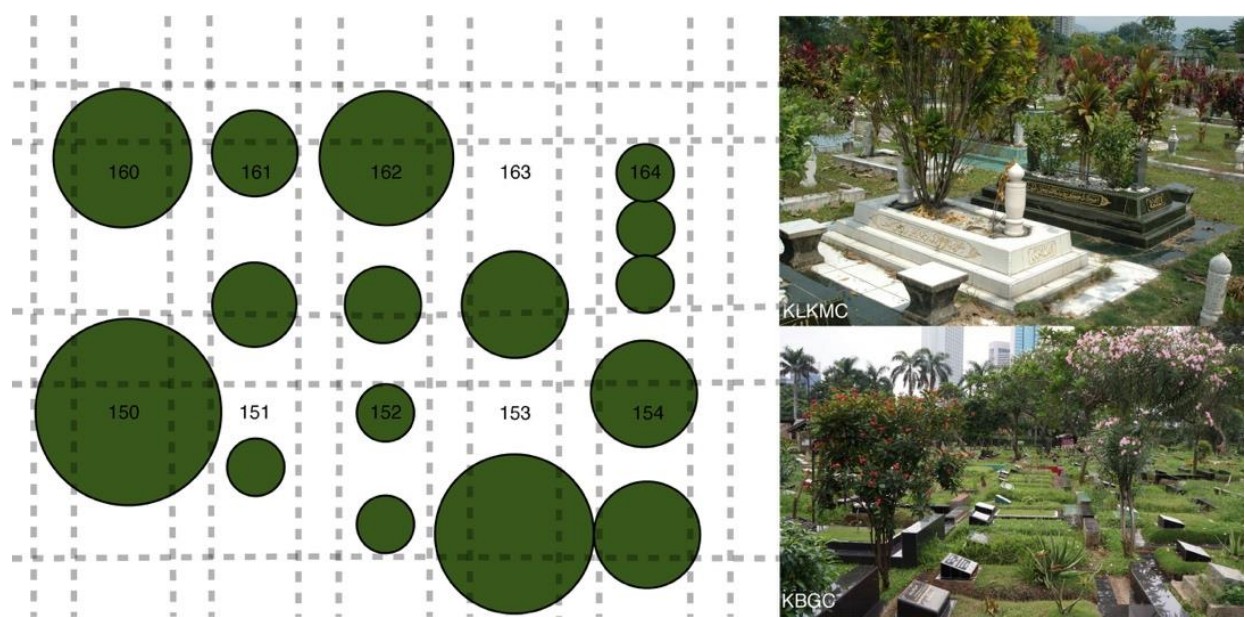

Figure 11: There are many forms of personal demarcation that have been encountered during the site visits. The diagram on the left depicts some of the variations of built-up personal demarcations. Pictures on the right show some of the actual structures found at KLKMC and KBGC.

Source: Author $(2011,2012)$

The other function of plants in Muslim cemeteries is for aesthetic reasons. In some public cemeteries such as KLKMC, KBGC and PKGC there are many variations of plants grown at the graves from multi-coloured foliage to towering trunks. The combination of these plants and the permanent structures has turned each grave into its own unique niche garden. However, Muslim cemeteries display the idea of 'garden' mainly through the varieties of plants grown over the graves, rather than focusing on the overall surrounding area. Yet, there are some examples where Muslim cemeteries have begun to adopt the 'garden' theme as an overall concept such as TSMC and SDHMP where random planting no longer exists. Here, trees not only play the role of enhancing the beautiful landscape of the surrounding area, but are also used to divide burial grounds into manageable burial spaces. The trees have been used to divide burial spaces into smaller sections. Each section is treated as a room or space that is supposed to create a sense of direction within the cemetery. Each burial space consists of no more than twenty graves in TSMP. In contrast to the old cemeteries, the structural planting at TSMC and SDHMP has been planned systematically since the beginning. This is a precautionary step that is necessary to create a pleasant experience for the visitors. Furthermore, the issue of visibility has been properly addressed at both sites. Trees are no longer allowed to be grown near the graves and therefore no longer perform their original function to pray for the dead. However, low height shrubberies and grasses are permitted and are still able to symbolise this spiritual purpose.

The abundance of random planting has sometimes created a visual barrier 
PLANNING MALAYSIA

Journal of the Malaysia Institute of Planners (2018)

for visitors trying to locate graves. TSMP and SDHMP present an example of a Muslim cemetery that is both accessible and pleasant (Figure 12). The random planting in all cemeteries has to change into a systematic arrangement to avoid the sense of disorder. Both case studies are an example that can be promoted to other Muslim cemeteries in KL and Jakarta. The type of shrubs permitted for planting over the graves should also be limited to structural branches, rather than species that have dense foliage. Visitors have to acknowledge the types of plants that are allowed to grow over graves and management need to use plants to clearly define burial spaces within the cemetery. The role of plants in TSMP and SDHMP has been extended to create a more park-like cemetery, where it is more convenient for people to navigate the area without any sense of confusion. Moreover, the role of plants in Muslim cemeteries should be seen as accommodating more than just a cultural practice. For this reason, the specific role of plants in Muslim cemeteries should be divided between functionality and aesthetic values.

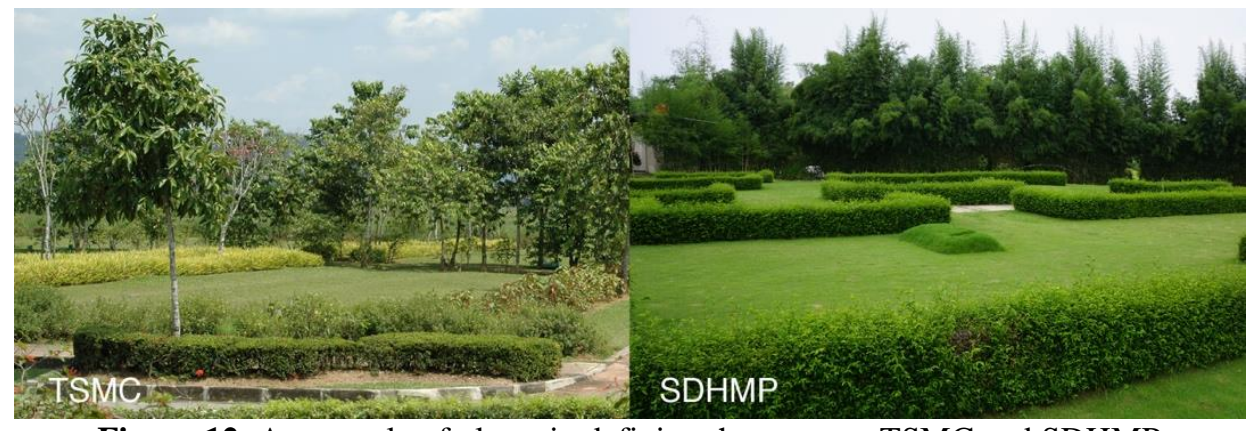

Figure 12: A new role of plants in defining the space at TSMC and SDHMP Source: Author (2011, 2012)

\section{PROPOSALS AND DESIGN GUIDELINES}

This research has formulated a design proposal that works around the limitations of Muslim burial customs as well as Islamic burial requirements. An assessment of utilisation of space inside Muslim cemeteries was explored by conducting critical examination of the three categories of Muslim burial practices described earlier. The design solutions for family plots, permanent structures and random plantings are found to be appropriately executed by re-examining the layout arrangement of the cemetery. The new design proposal for the layout of Muslim cemeteries suggests that burial plots be arranged in one row, with each side of the grave accessible to footpaths as shown in Figure 13. Footpath-cum-ritual space will be introduced into Muslim cemeteries as one of the important features in reviving the layout plan. These footpaths will provide the space Muslims need for performing the ritual activities related to the funerary practices. This design proposal will maintain the same features that are found in conventional Muslim 
Mohamad Reza Mohamed Afla

Spatial Regeneration of Muslim Burial Practices in the Metropolitan Areas of Kuala Lumpur and Jakarta

cemeteries by having two points of access for each grave. In terms of softscape, trees and shrubs could be used to form outdoor rooms as a means to provide emotional support for bereaved families. The landscape of Muslim cemeteries could also serve as utilitarian in accommodating the rituals that happen at the gravesite. Figure 14 shows the design guidelines in the form of diagrams that can be implemented in public cemeteries. These diagrams could serve as a planning guideline to strengthen the spatial regeneration in Muslim cemeteries.

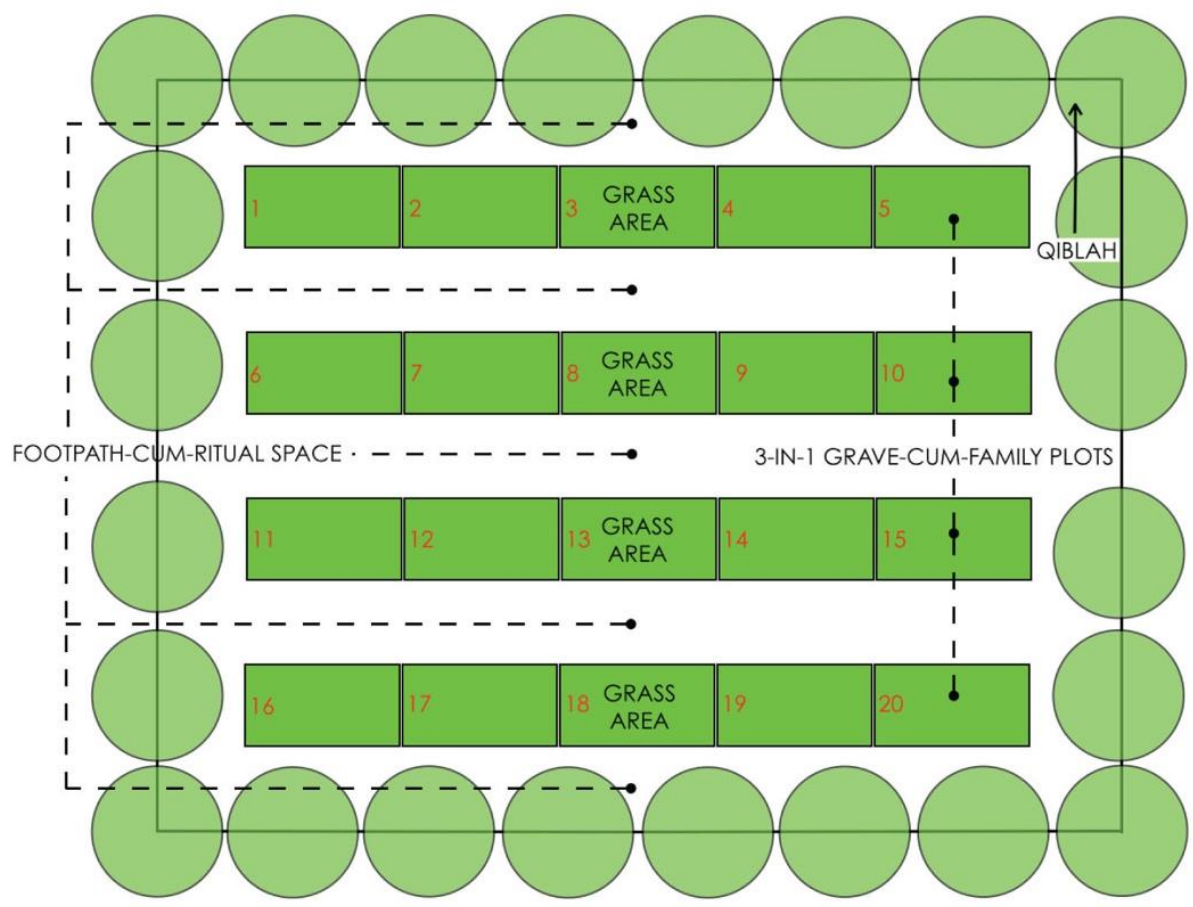

Figure 13: On this plan, every grave is covered with grass to maintain the semblance of 'green factors' that is commonly associated with traditional Muslim graves. The plan also shows the merging of footpaths and ritual spaces as one row rather than being separated.

Source: Author (2012) 

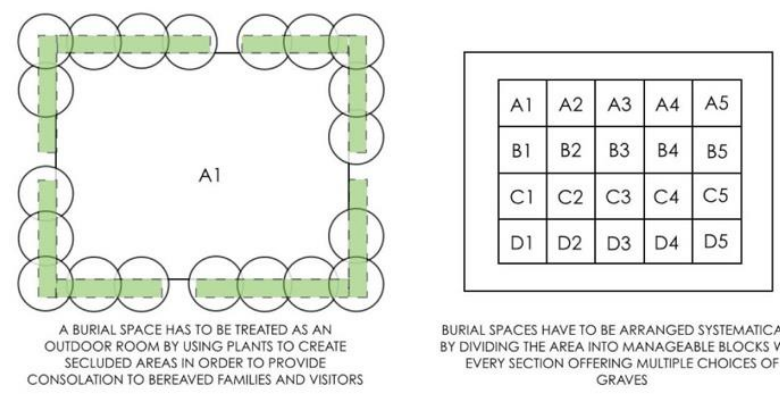

BURIAL SPACES HAVE TO BE ARRANGED SYSTEMATICALIY Y DIVIDING THE AREA INTO MANAGEABLE BDOCKS WLITH
EVERY SECTION OFEFPING MUITPLECHOCES OF
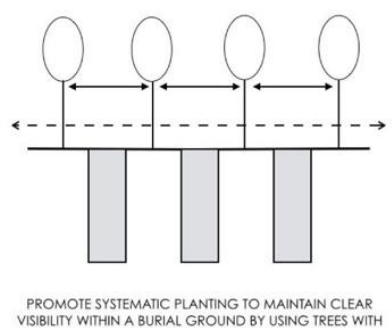
VERTICAL FORM AND LOW DENSE FOLIAGE
VITY WE

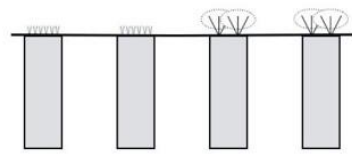

USE GRASSES OVER THE GRAVES TO PERFORM THE SPIRIUAL ROLES. OTHERWISE LOW LYING SHRUBS WITH SHOULD BE USED AS A AUBSTIIUTE
SHALE
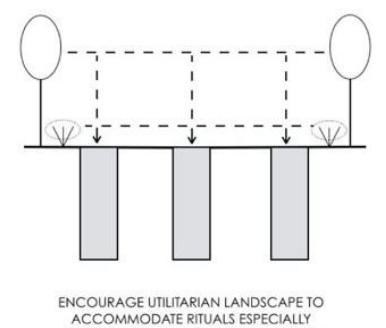
ACCOMMODATE RTUALS ESPECIALIY
SPREADING FLOWERS OVER THE GRAVE

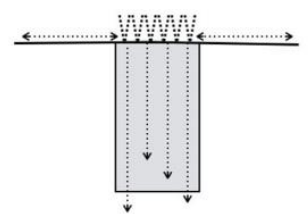

ENCOURAGE SOFISCAPE OVER THE GRAVES TO GREENER URBAN ENVIRONMENT
GRE TSOR
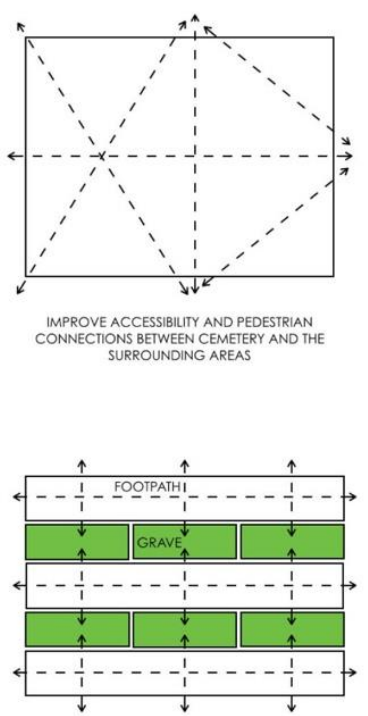

TWO SIDES ACCESS FOR EVERY GRAVE TO
ACCOMMODATE THE RTIUALS INVOLVED DURING AND AFIER BURIAL

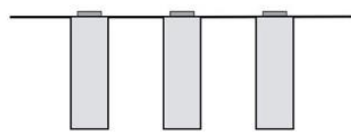

ENCOURAGE ZERO STRUCTURES OVER THE

Figure 14: Design guidelines for plan layouts and arrangement of public cemeteries. Source: Author (2012)

\section{CONCLUSION}

This article has taken examples from various corners of Kuala Lumpur and Jakarta in order to transform Muslim burial practices into the $21^{\text {st }}$ century. From the site visits conducted throughout the case studies, it is evident that the municipals in each city have different approaches to accommodating burial infrastructure for its Muslim population. There have been some efforts to transform aspects of burial practices in a few places around KL and Jakarta. This signifies that changes of practice in urban cemeteries have begun to take place. Finally, this article identifies ideal prototypes for grave plots and cemetery layouts that can be adapted to Muslim cemeteries based on the analysis gathered from the case studies. 
Mohamad Reza Mohamed Afla

Spatial Regeneration of Muslim Burial Practices in the Metropolitan Areas of Kuala Lumpur and Jakarta

\section{REFERENCES}

Bougas, W. A. (1988). Islamic cemeteries in Patani. Kuala Lumpur: The Malaysian Historical Society.

Dafni, A., Lev, E., Beckmann, S., \& Eichberger, C. (2006). Ritual plants of Muslim graveyards in northern Israel. Journal of Ethnobiology and Ethnomedicine, 2, 38.

Doss, E. (2002). Death, art and memory in the public sphere: The visual and material culture of grief in contemporary America. Mortality, 7, 63-82.

Ely, A., \& Howe, M. (2002). Cemeteryscape. The Journal of the Institute of Burial \& Cremation Administration, Summer 2002. Retrieved from http://www.maellp.co.uk/press/Citycemetery_essay.pdf

Forbes, D. K. (1996). Asian metropolis: Urbanisation and the Southeast Asian city. Melbourne: Oxford University Press.

Francis, D. (2003). Cemeteries as cultural landscapes. Mortality, 8, 222-227.

Gibson, M. (2004). Melancholy objects. Mortality, 9, 285-299.

Hallam, E., \& Hockey, J. L. (2001). Death, memory, and material culture. Oxford: Berg.

Hamnett, S., \& Forbes, D. K. (2011). Risks, resilience and planning in Asian cities. In S. Hamnett, \& D. K. Forbes (Eds.), Planning Asian cities: Risks and resilience (pp. 1-37). New York: Routledge.

Hashim, S. (2007). Kematian dan pengurusan jenazah [Death and funeral management] Johor: Universiti Teknologi Malaysia.

Iqba, Z. (2011). McDonaldization, Islamic teachings, and funerary practices in Kuwait. OMEGA, 63(1), 95-112.

Ismail, F. (2008). Muslim burial practices. The Journal of the Institute of Cemetery \& Crematorium Management, 76, 49-50.

Ismail, W. N. W., Arabi, F., Husini, E. M., Zolkifly, F. N. S., Darus, Z. M., Jaafar, N. H. A., \& Manaf, A. A. (2017). The establishment of Islamic dwelling principles for the Malaysian communities. Advanced Science Letters, 23(7), 6289-6293.

Kurniawan, K. R. (2008, August). Marketing graves: Changing paradigm of a burial ground from a city of death to a city of amusement in San Diego Hills Cemetery in Cikarang West Java. ARTEPOLIS 2 International Conference and Workshop on Creative Communities and the Making of Place. August 8-9, 2008, Bandung, Indonesia.

Limited cemetery space prompts call to public to reuse graves (2011). The Jakarta Post. Retrieved from http://www.thejakartapost.com/news/2002/07/13/limited-cemetery-space-prompts-call- public-reuse-graves.html.

Nirmala, R., \& Primanita, A. (2011). Jakarta's grave need for green may be filled by cemeteries. The Jakarta Globe. Retrieved from http://www.thejakartaglobe.com/archive/jakartas- grave-need-for-green-maybe-filled-by-cemeteries/346983/

No more space in Central Jakarta cemeteries (2011). The Jakarta Post. Retrieved from http://www.thejakartapost.com/news/2011/03/12/no-more-space-c-jakartacemeter- ies.html

Omer, S. (2008). Death, graveyards and funerary architecture in Islam. Kuala Lumpur: AS Noordeen. 
PLANNING MALAYSIA

Journal of the Malaysia Institute of Planners (2018)

Rahim, S. (2011). More Muslim cemetery plots. New Straits Times. Retrieved from http://www.nst.com.my/life-times/health/more-muslim-cemetery-plots-1.9206

Rimmer, P. J., \& Dick, H. W. (2009). The city in Southeast Asia: Patterns, processes and policy. Honolulu: University of Hawaii Press.

Salim, W., \& Firman, T. (2011). Governing the Jakarta city-region: history, challenges, risks, and strategies. In S. Hamnett, \& D. K. Forbes (Eds.), Planning Asian cities: Risks and resilience (pp. 241-259). New York: Routledge.

Uslu, A., Baris, E., \& Erdogan, E. (2009). Ecological concerns over cemeteries. African Journal of Agricultural Research, 4, 1505-1511

Received: $1^{\text {st }}$ June 2018. Accepted: $1^{\text {st }}$ December 2018 